Ethiopian Journal of Environmental Studies \& Management 8(5): 517 - 529, 2015.

ISSN:1998-0507

doi: http://dx.doi.org/10.4314/ejesm.v8i5.5

Submitted: February 04, 2015

Accepted: June 23, 2015

\title{
COMPOSITION AND DISTRIBUTION OF DRAGONFLIES AND DAMSELFLIES (INSECTA: ODONATA) IN ILOYIN FOREST, AKURE, SOUTHWESTERN NIGERIA
}

*ADU, B.W., ${ }^{1}$ AKINDELE, E.0. ${ }^{2}$ AND OBADOFIN, A.A. ${ }^{1}$

${ }^{1}$ Department of Biological Sciences, Ondo State University of Science and Technology, Okitipupa, Ondo State, Nigeria

${ }^{2}$ Department of Zoology, Obafemi Awolowo University, Ile-Ife, Osun State, Nigeria

\begin{abstract}
Odonate fauna of Iloyin Forest was studied from October to December 2009 to have an overview of the species composition and distribution with the threat of deforestation in the area. Adult species were collected once a week using a sweep net throughout the period of the study from three study sites (denoted as I, II and III) with varying levels of anthropogenic disturbance. A total of 76 species belonging to eight families were recorded in the forest. The two most abundant families in the forest were the Libellulidae (Anisoptera) and Coenagrionidae (Zygoptera). Palpolpeura portia, P.lucia and Congothemis dubia were the dominant species of Libellulidae, while Pseudagrion kersteni was the dominant coenagrionid. Some species of Odonata usually associated with shaded forests were encountered in two of the study sites. The highest diversity and evenness indices were recorded at Site I, followed by Site II and the least recorded at Site III. Although shade-loving species recorded in the study area was an indication of its richness in forest Odonata, some may have however become locally endangered or extinct as a result of deforestation. A check in the rate of deforestation could preserve the few forest (endangered) species and restore the locally extinct ones that changed habitats.
\end{abstract}

Key Words: Biodiversity, Conservation, Disturbance, Forest, Freshwater, Odonata

\section{Introduction}

In the past, there has been a general neglect of invertebrates in conservation programmes owing to a lack of knowledge of invertebrate species ecology and limited public enthusiasm for less, visible, and aesthetically less attractive species (Bratton, 1991). However, there is a growing awareness that invertebrates are important intrinsic components of biological communities and of ecological processes, and provide resources of direct human benefits (Wells et al., 1983). Dragonflies and damselflies for instance, are sensitive to structural habitat quality (e.g. forest cover and water quality). They can function as flagship for water conservation, not only for water-rich habitats but also for habitat where water is scarce (Dijkstra et. al., 2009). Dragonflies and damselflies can be used as bioindicator for evaluating environmental changes in long term (biogeography) and short term (conservation biology) studies (O'Neil and Paulson, 2001; Dijkstra, 2006).

Dragonflies and Damselflies are aquatic insects that are found in freshwater habitats such as rivers, streams, lakes, ponds and all

*Corresponding author: Adu, B.W.

Email: williamsadubabs@yahoo.com 
kinds of natural and artificial bodies of water found within the mainland. Owing to their stages of developments, these insects occupy two habitats during their life cycle: the terrestrial and aquatic habitats. Adults are terrestrial while the immature stage (larva) is predominantly aquatic. This amphibious attribute makes them a versatile instrument for the assessment of water condition and forest landscape. Odonata generally love to roost in the sun especially around open water bodies. Some species spend the largest part of their time in open places. Such species have broad niche (Corbet, 1999; Dijkstra, 2007). They also have high propensity to survive in partially degraded habitats, and are capable of rapidly colonizing new or restored habitats. Some species spend brief moments in open places while larger parts of their time are spent in shaded places. Such species have narrow niche and are poor colonizer of temporary habitats especially deforested habitats. However those with narrow niche (Stenotopic types) are usually endangered as a result of human activities. Absence of such species in forests within their expected biogeographical region could be an indication that anthropogenic activities within the ecosystem are too harsh for them to tolerate.

Dispersal capabilities of Odonata correspond to their ecological requirements. Stenotopic species are poorly dispersed while the ubiquitous species are pioneers of temporary habitat (created by anthropogenic activity). According to Clausnitzer (2003) ubiquitous species prevail in disturbed or temporary waters, while pristine streams, seepage and swamp forest harbor a wealth of more vulnerable, often localized species. The responses of stenotopic and eurytopic (ubiquitous) species to environmental changes cause them to be used in the assessment of habitat connectivity (Clausnitzer, 2003; Dijkstra and Lempert, 2003). The presence of diverse forest species (especially narrow niche species) in a forest environment reveals that the forest is in good physical condition (Samways, 1989; Corbet, 1999). An environment dominated by the ubiquitous species revealed that such environment is disturbed. The knowledge of the assemblages of species of Odonata has the propensity to discriminate between various biotopes found in forest, which is a reflection of changes in structures and architecture of forest vegetation (Hawking and New, 1995).

There is evidence that excessive consumption of resources has happened in a number of human societies, leading to population declines and leaving a greatly impoverished natural environment. (Hambler and Canney, 2013). For instance, the location of Federal Polytechnic in Iloyin village Akure in 1977 (later relocated to Ado-Ekiti) and the establishment Federal University of Technology Akure (FUTA) in 1981 in the same area led to massive deforestation of the area. The forest is further threatened by residential layout already approved by the government, and this has heightened the rate of deforestation for residential and farming purposes. Furthermore, canalization and construction of concrete bridges over the streams have further endangered the odonate larvae and adults in the surrounding riparian vegetations. The objectives of this study were to sample and identify as many adult specimens of dragonflies and damselflies encountered in the forest; to determine the composition and distribution of dragonfly and damselfly in Iloyin Forest; and to assess the effect of anthropogenic activities on the diversity and distribution of the odonate fauna in the forest. 


\section{Materials and Methods ` Study Area}

This study was carried out in the remainder of the forest, outside the Federal University of Technology. Iloyin forest is located in Akure (Latitude $7^{\circ} 17^{\prime} 24.79^{\prime \prime} \mathrm{N}$ and Longitude $\left.5^{\circ} 08^{\prime} 42.98^{\prime \prime} \mathrm{E}\right)$. It is a secondary re-growth forest with inland water bodies (such as small rivers, streams and swamps) characterizing its landscape. Three study sites were identified in the forest (Study site I, Study site II and Study site III). Selections of the sites were based on the microhabitats preferred by dragonflies and damselflies. Such included the presence of freshwater bodies, hydrological characteristics of the water bodies like water clarity and water current velocity, and also the vegetative structure of the forest.

Study site I (Latitude $7^{\circ} 17^{\prime} 25.966^{\prime \prime} \mathrm{N}$ and Longitude $5^{\circ} 08^{\prime} 40.59^{\prime \prime} \mathrm{E}$, elevation $353.9 \mathrm{ft}$ ) is a big stream that was far away from residential area. Apart from forest vegetation, parts of the physical structure of the site include farming activities such as cocoa plantation. There were evidences of regular deforestation (i.e. logging of wood) and clearance of riparian vegetation at the stream. Tall trees and short trees with undergrowth plants are also part of the prevailing physical structure of the forest. The study site was partly shaded as a result of the tall trees that form part of the riparian vegetation.

Study site II (Latitude $7^{\circ} 17^{\prime} 19.60^{\prime \prime} \mathrm{N}$ and Longitude $5^{\circ} 08^{\prime} 42$. 50" $\mathrm{E}$, elevation $347.8 \mathrm{ft}$ ) was a small, slowly flowing runnel. Some residential buildings were adjacent to the runnel. The surrounding of the runnel was very marshy. Dead organic matter such as dead leaves, wood and other organic matter were on the water, a situation that was responsible for the slow flowing of the water thereby making the surrounding of the site marshy. Adjacent vegetations to the study site included agroforest and abandoned farm lands that had been over grown by bush.

Study site III (Latitude $7^{\circ} 17^{\prime} 21.38^{\prime \prime} \mathrm{N}$ and Longitude $5^{\circ} 08^{\prime} 36$. $02^{\prime \prime} \mathrm{E}$, elevation $365.2 \mathrm{ft}$ ) was a forest stream. It is a secondary forest dominated by hardwood trees with undergrowth vegetation. Few abandoned buildings overgrown by bush constituted a part of the physical structure of this site. The water current of the stream was slow as a result of submerged and dead organic debris. Few boulders also constituted part of the stream bed.

Earliest studies on Odonata in Nigeria were carried out by Pinhey (1958) and Gamble (1960). Both embarked on surveying Odonata of the country. Gambles focused surveying north central part of the country while Pinhey took the inventory of Odonata of the south eastern part. Adetunji and Parr (1974) studied the effect of colour change in species of Odonata with particular reference to Brachythemis leucosticte. The study revealed the effect of ambient temperature on Odonata pigment (melanization), a phenomenal that had only been observed among member of this insect order (Corbet, 1999). 


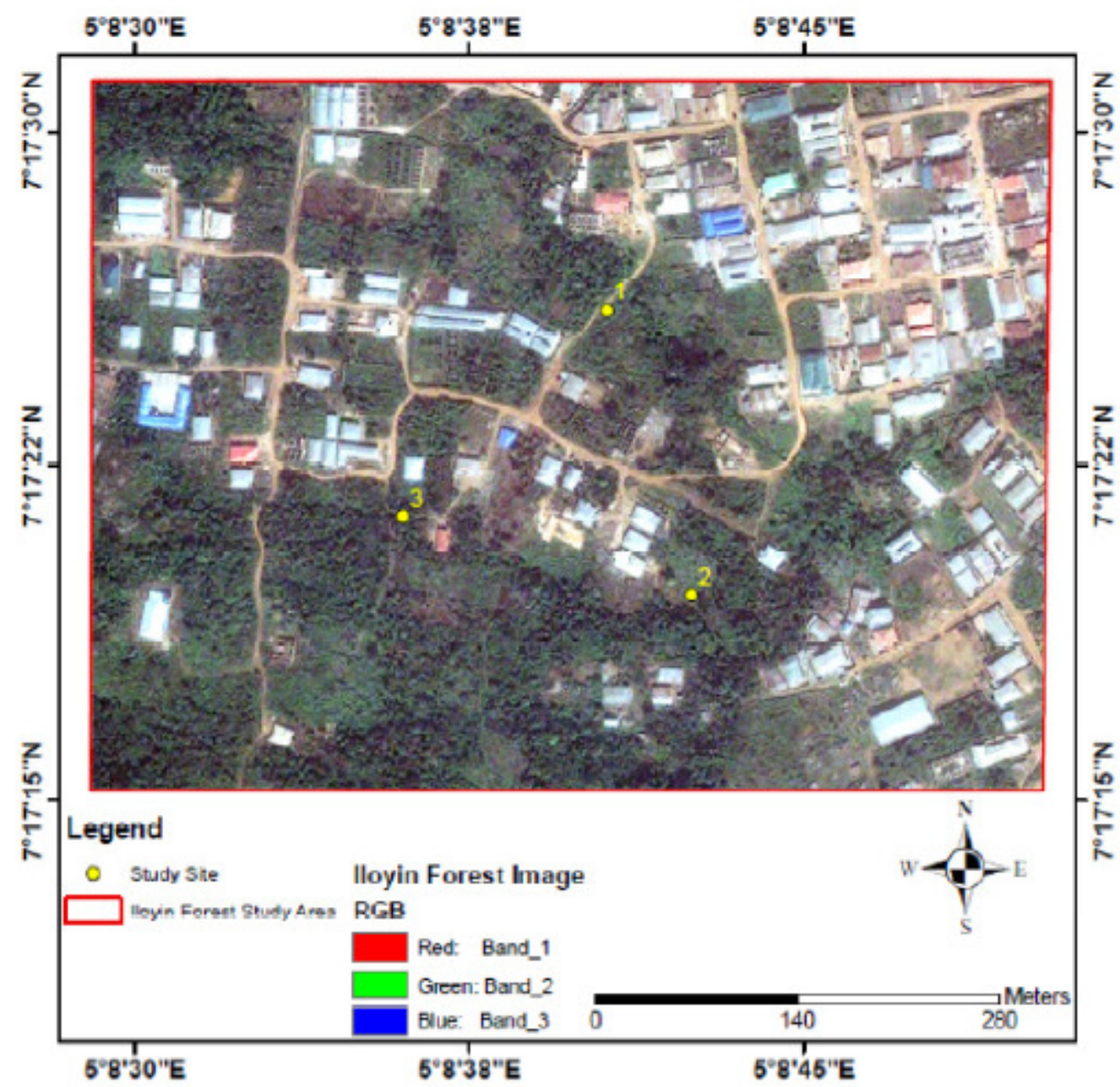

Figure 1: Map of Iloyin Forest 'o' showing the three study sites

\section{Sampling Method}

Specimens of adult Odonata were collected in the forest using an insect sweep net (70 $\mathrm{cm}$ diameter with a long handle) (Ausden, 1996). Sampling was carried once a week for a period of three months; from 9.00 am to $4.00 \mathrm{pm}$ on every sampling day. Each specimen caught was placed in a triangular envelope with their wing folded together above the body. Pair specimens caught in tandem were placed together inside an envelope. Detailed information about every specimen was written at the back of each envelope with pencil (e. g. locality, date, name of collector and microhabitat of the insect). All specimens were soaked inside acetone for a minimum of 12 hours for preservation (Vick, 2003), after which the specimens were carefully removed and air-dried. The preserved specimens were placed inside envelopes and stored in insect boxes.

\section{Identification of Specimens}

All specimens collected were identified to the lowest taxonomical level. Species which can be identified easily were generally common in the forest. Such species were not always collected for laboratory identification (for conservation purpose). All collected specimens were examined under binocular dissecting microscope for identification, following standard identification manuals such as Silsby and Trueman (2002), Vick (2003). 
The specimens were also compared with previous collections of identified species of dragonflies and damselflies from tropical forests in southwestern Nigeria, by the Department of Zoology, Obafemi Awolowo University, Ile-Ife.

\section{Data Analysis}

All data collected at the study sites were analyzed using relevant statistical packages (e.g. PAST). The diversity indices used include Margalef index, Shannon Weiner diversity index, Simpson's dominance index and Evenness index. Soerensen's Quotient was used for the determination of similarities of odonate fauna among the three study sites.

\section{Results}

\section{Species Richness and Distribution}

Species richness and abundance of dragonflies and damselflies for each study site in Iloyin Forest are presented in Table 1. A total of 1,494 Odonatan specimens, comprising eight families and 76 species were recorded. Suborder Anisoptera comprised two families (Gomphidae and Libellulidae) and 29 species, while suborder Zygoptera comprised six families (Calopterygidae, Megapodagrionidae, Chlorocyphidae, Coenagrionidae, Platycnemididae and Protoneuridae) and 47 species. Study site I had the largest number of species (69), followed by Study site 3 (51 species), while study site II had the lowest number of species (49). In terms of species richness, Libellulidae recorded the highest number of species followed by Coenagrionidae, while Families Gomphidae and Megapodagrionidae were monospecific. The assemblage of dragonflies and damselflies in the forest can be categorized into two broad niches; ubiquitous species, majority of which were collected in open places around the stream bank. Some were also found in open land in the forest, around the abandoned buildings under construction and in bushes and farms; and forest species which were mainly found in the shaded places of the forest.

\section{Abundance of Odonata}

Spatially, there was a large variation in the abundance of Odonata among the sites with Site I recording the largest number of individuals, followed by Site III and lastly Site II $(\mathrm{p}<0.001)$. The most abundant libellulids in this study were Palpopleura portia, P.lucia, Congothemis dubia, Brachythemis leucosticte, Chalcostephia flavifrons and Sympetrum navasi. Pseudagrion kersteni was the most abundant coenagrionid followed by $P$. melanicterum. They could be considered as the most widespread species in this study because they were found in all the study sites in large numbers.

In this study, the recorded species were classified into three categories based on their abundance: (i) Dominant > 29 individuals, (ii) Common $10-29$ and (iii) Rare $<10$ individuals. Eleven species could be described as being dominant, 59 species were common while six species were rare. Eight out of the 11 dominant species belonged to the Family Libellulidae, three species were of the Family Calopterygidae and one species of Coenagrionidae (Pseudagrion kersteni). Although Families Gomphidae and Megapodagrionidae were represented by only one species each (Lestinogomphus angustus and Neurolestes trinervis respectively), their members were however classified as common species since they comprised 18 and 14 individuals respectively. Figures 1 and 3 present the relative abundance of dominant and rare species of Odonata in the forest.

Ten most occurring species of Odonata (10 -45 individuals) in each study site in the forest are shown in Table 2. The purpose of this designation was to fully comprehend the dominant species of Odonata occurring 
in the three study sites, bearing in mind their landscapes. Palpopleura portia and $P$. lucia occurring prominently in all sites. Congothemis dubia was the dominant species of Odonata in Sites I and II while Brachythemis lacustris was the dominant in Site III.

A summary of the diversity, evenness and dominance indices calculated for the three study sites sampled are presented in Table 3. Shannon Weiner diversity Index $\left(H^{\prime}\right)$ was highest in Study site I, followed by Study sites II and III. Margalef Diversity Index also showed that Study site I recorded the highest species diversity among the three sites. However the trend differs from the Shannon Weiner diversity index in that study site III had a higher value of Margalef than Site II. Evenness (E) and Simpson's dominance index followed the same trend as the Shannon Weiner diversity index. Soerensen's quotients of the study sites revealed that study sites I and III were the most similar paired sites (0.77), and was closely followed by paired Study sites I and II (0.76). Furthermore, Sites I and III had 47 species in common, while Stations I and II had 46 species in common.

Table 1: Composition and distribution of dragonflies and damselflies in the study sites of Iloyin Forest, Akure, Southwestern Nigeria (October-December, 2009)

\begin{tabular}{l}
\hline TAXA \\
\hline Suborder Anisoptera \\
Family Gomphidae \\
Lestinogomphus angustus Martins, 1911 \\
Family Libellulidae \\
Atoconeura luxata Dijkstra,2006 \\
Brachythemis lacustris (Kirby,1889) \\
Brachythemis leucosticte (Burmeister,1839) \\
Chalcostephia flavifrons Kirby,1889 \\
Congothemis dubia (Frazer,1954) \\
Congothemis leakeyi (Pinhey, 1955) \\
Congothemis erythraea (Brulle,1832) \\
Congothemis sanguinolenta (Burmeister,1839) \\
Hadrothemis infesta (Karsch,1891) \\
Lokia erythromelas (Ris,1910) \\
Neodythemis klingi (Karsch,1890) \\
Nesciothemis nigeriensis Gambles,1966) \\
Nesciothemis farinose (Forster,1898) \\
Nesciothemis pujoli Pinhey,1971 \\
Orthetrum africanum (Selys,1887) \\
Orthetrum brachiale (Palisot de Beauvois,1817) \\
Orthetrum caffrum (Burmeister,1839) \\
Orthetrum chrysostigma (Burmeister,1839) \\
Orthetrum hintzi Schmidt,1951 \\
Orthetrum julia Kirby,1900 \\
Orthetrum machadoi Longfield,1955 \\
Orthetrum stemmale (Burmeister,1839) \\
Palpopleura lucia (Drury,1773) \\
Palpopleura portia (Drury,1773) \\
Sympetrum fronscolmobii (Selys,1840) \\
Sympetrum navasi Lacroix,1921
\end{tabular}

Site 1 Site 2

Site 3

Total

$\begin{array}{llll}13 & 0 & 5 & 18 \\ 0 & 15 & 4 & 19 \\ 12 & 0 & 15 & 27 \\ 14 & 12 & 7 & 33 \\ 12 & 13 & 7 & 32 \\ 18 & 14 & 6 & 38 \\ 6 & 18 & 7 & 31 \\ 0 & 6 & 8 & 14 \\ 0 & 8 & 8 & 16 \\ 0 & 0 & 12 & 12 \\ 10 & 8 & 3 & 21 \\ 0 & 0 & 6 & 6 \\ 8 & 10 & 3 & 21 \\ 8 & 0 & 0 & 8 \\ 10 & 6 & 3 & 19 \\ 6 & 12 & 3 & 21 \\ 8 & 8 & 2 & 18 \\ 8 & 8 & 0 & 16 \\ 13 & 10 & 3 & 26 \\ 9 & 0 & 4 & 13 \\ 16 & 6 & 0 & 22 \\ 6 & 8 & 0 & 14 \\ 8 & 8 & 6 & 22 \\ 14 & 16 & 12 & 42 \\ 14 & 17 & 11 & 42 \\ 0 & 6 & 2 & 8 \\ 8 & 16 & 8 & 32 \\ & & & \end{array}$


Trithemis dichroa Karsch, 1893

Trithemis imitate Pinhey 1961

Suborder Zygoptera

Family Calopterygidae

Phaon camerunensis Sjöstedt, 1900

Phaon iridipennis (Burmeister, 1839)

Saphon ciliata (Burmeister, 1839)

Umma cincta (Hagen in Sélys, 1853)

Umma declivium Förster, 1906

Umma mesostigma (Selys, 1879)

Umma saphirina Förster, 1916

Umma mesumbei Vick, 2003

Family Chlorocyphidae

Chlorocypha cancellata (Selys, 1879)

Chlorocypha centripunctata Gambles, 1975

Chlorocypha consueta (Karsch, 1899)

Chlorocypha dahli Fraser, 1956

Chlorocypha autorea

Chlorocypha luminosa (Karsch, 1893)

Chlorocypha victorae (Förster, 1914)

Chlorocypha dispar (Palisot de Beauvois, 1807)

Chlorocypha glauca (Selys, 1879)

Chlorocypha curta (Hagen in Selys, 1853)

Chlorocypha radix Longfield, 1959

Chlorocypha flammea Dijkstra,2009

Chlorocypha trifaria (Karsch, 1899)

Chlorocypha pyriformosa Fraser, 1947

Platycypha auripes (Förster, 1906)

Platycypha eliseva Dijkstra, 2008

Family Coenagrionidae

Aciagrion heterostica Fraser, 1955

Aciagrion hamoni Fraser, 1955

Africallagma vaginale Sjostedt,1917

Ceriagrion glabrum (Burmeister, 1839)

Ceriagrion suave Ris, 1921

Ischnura senegalensis (Rambur, 1842)

Pseudagrion kersteni (Gerstäcker, 1869)

Pseudagrion melanicterum Selys, 1876

Pseudagrion risi Schmidt, 1936

Pseudagrion sublacteum (Karsch, 1893)

Pseudagrion torridum Selys, 1876

Teinobasis alluaudi (Martin, 1896)

Family Megapodagrionidae

Neurolestes trinervis Selys, 1885

Family Platycnemididae

Mesocnemis saralisa Dijkstra, 2008

Mesocnemis singularis Karsch, 1891

Oreocnemis phoenix Pinhey, 1971

Family Protoneuridae

Chlorocnemis nigripesi Selys, 1886

Chlorocnemis superb Schmidt, 1951

$\begin{array}{lll}12 & 6 & 30 \\ 10 & 0 & 25 \\ 14 & 8 & 31 \\ 17 & 9 & 32 \\ 0 & 3 & 8 \\ 0 & 8 & 19 \\ 0 & 6 & 17 \\ 6 & 7 & 26 \\ & & \\ 0 & 2 & 14 \\ 0 & 2 & 14 \\ 0 & 0 & 14 \\ 0 & 4 & 14 \\ 0 & 3 & 12 \\ 0 & 0 & 10 \\ 0 & 0 & 9 \\ 0 & 4 & 16 \\ 5 & 0 & 12 \\ 0 & 0 & 17 \\ 10 & 0 & 23 \\ 0 & 7 & 16 \\ 0 & 7 & 15 \\ 0 & 0 & 7 \\ 13 & 3 & 21 \\ 15 & 3 & 22\end{array}$

9

9

12

9

9

10

18

13

15

12

8

8

5

8

10

8

10

8

$\begin{array}{lll}6 & 0 & 15 \\ 5 & 0 & 14 \\ 11 & 0 & 23 \\ 13 & 0 & 22 \\ 11 & 0 & 20 \\ 12 & 5 & 27 \\ 14 & 4 & 36 \\ 10 & 5 & 28 \\ 9 & 3 & 27 \\ 10 & 0 & 22 \\ 9 & 0 & 17 \\ 12 & 1 & 21 \\ & & \\ 7 & 2 & 14 \\ & & \\ 9 & 0 & 17 \\ 8 & 0 & 18 \\ 7 & 0 & 15 \\ & & \\ 4 & 0 & 14 \\ 9 & 5 & 22\end{array}$




\begin{tabular}{lllll} 
Elattoneura centrafricana Lindley, 1976 & 8 & 12 & 5 & 25 \\
Elattoneura incerta Pinhey, 1962 & 12 & 0 & 4 & 16 \\
Elattoneura nigra Kimmins, 1938 & 14 & 0 & 5 & 19 \\
Elattoneura lliba Legrand, 1985 & 10 & 0 & 2 & 12 \\
Elattoneura pasquinii Consiglio, 1978 & 8 & 0 & 3 & 11 \\
\hline Total & 709 & 511 & 274 & 1494 \\
\hline ANOVA: F=30.58; $<0.001$ & & &
\end{tabular}

\section{Discussion}

Odonate fauna of Iloyin Forest was dominated by Libellulidae which accounted for nearly $40 \%$ of the total abundance. Several studies have also shown that Libellulidae is widely represented in many forests globally and locally (e.g. Che Salmah 1996, 2001; Che Salmah and Wahizatul Alfan, 2004; Adu and Ogbogu 2011; Adu 2012). Libellulidae recorded the highest number of species richness in the forest. The least represented family in the forest was Gomphidae with the occurrence of only one species, Lestinogomphus angustus. This species was collected at Study Site I. L. angustus is habitat tolerant (Vick, 2003), although it is mostly found in streams shaded by gallery forest (Samways, 2008; Dijkstra and Claunitzer in press). Study Site I possessed the vegetative architecture so described and such habitats could provide the right shade and light suitable for its comfort.

Palpopleura portia and P. lucia were found to be quite abundant in all the study sites. The reason for this is that these species prefer open water bodies especially streams and ponds (O'Neill and Paulson, 2001; Dijkista and Clausnitzer in press). Moreover this study was conducted incidentally during the flight period (November - May) of the species (Samways, 2008). Palpopleura portial and $P$. lucia were also sampled at road side pools and they were conspicuously found perching on twigs, grasses and stems in all the sites. The two species are among the libellulids that have broad niche (eurytopic), and are pioneers of temporary habitat (Dijkistra, 2007; Adu, 2012) and therefore their presence in a place like Iloyin forest, which is in a state of transition into a residential community was expected.

The Congothemis is endemic to Afrotropical forest especially from Guinea to Central Africa (Dijkistra, 2007). Four species of this genus (Congothemis) were sampled in the forest. Among which $C$. dubia was the most dominant. This may not be unconnected with the presence of forest vegetation architecture which provides the needed atmosphere to thrive. For instance the tree crowns could provide the right roosting spot for the adults while the twigs and shrub at the water bank are for the slow flier tenera adults to perch.

Two species of Brachythemis were recorded in the forest (B.lacustris and $B$. leucosticte). B. leucosticte was recorded in the three sites while B. lacustris occurred in all but Site II. Brachythemis has been reported to be generally favoured by standing or slow-flowing water; rivers or streams (Samways, 2008). However $B$. lacustris is specifically favoured by slowflowing rivers with bear ground bank (Dijkstra and Clausnitzer in press). The absence of B. lacustris in Study Site II which was a small, slow flowing runnel with swampy bank corroborates Dijkstra and Clausnitzer's assertion. This habitat may also not have provided a suitable perching ground for the species.

All the biodiversity indices used revealed that the forest was ecologically healthy. For instance Shannon-Weiner diversity index values at all the study sites were above 3.0 which was an indication of a stable habitat structure, while values that 
are less than 1.0 indicate that there is pollution and degradation of the habitat structure (Shannon, 1948; Mandaville, 2002). All the values were greater than 7.0 and this shows that the forest environment was in a healthy condition. (Lenat et al., 1980). The values obtained from the evenness index at the sites shows that Odonate fauna were well distributed in the forest. For instance none of the values obtained fell below 0.5. The least evenness index value was 0.97 which was much closer to 1.0 than 0.5. Although Iloyin forest is in a state of transition to a residential community, the present state is still hygienic for some species of Odonata to thrive as revealed by the biodiversity indices. However the Odonata community structure has changed due to deforestation and other anthropogenic activities going on in the forest. For instance the stenotopic Odonata species which are mostly forest dweller are gradually disappearing while the eurytopic ones which can cope with the changing vegetation landscape have colonized the forest.

There was a significant disparity $(p<0.001)$ between Site I (forest zone), Site II and Site III in terms of distribution, and this shows that the remaining fragments of Iloyin Forest still serve as a refuge for forest species of dragonflies and damselflies, while the ubiquitous species were found roaming about in the open areas. The paucity of forest species at Study sites II and III could be attributed to construction works and farming practices in the forest. The survival of few remaining forest species is however doubtful in a few years to come as a result of the prevailing land use scheme of the forest. With the situation on ground one can predict that Iloyin Forest would fully metamorphose into a residential area in few years to come, except concerted efforts are put in place to conserve the remaining fragments of the forest. This situation is detrimental to the assemblage of localized Odonata species and perhaps other organisms inhabiting the forest, and is in agreement with Corbet (1999).

The spatial distribution of Odonata in this study was a reflection of the nature of freshwaters in each study site. Site II which had a runnel recorded the lowest number of species, while Site I which had a big stream recorded the highest number of species. The physical nature of the water body and the riparian vegetation of the study sites could have contributed to the composition and distribution of species of Odonata occurring in the forest. It is a well-known fact that Odonata larvae are part of the macroinvertebrate assemblage in freshwater systems whose structures are affected by riparian forests (Barton et al., 1985).

Riparian forests have been shown to affect the food quality and quantity for macroinvertebrates directly through inputs of particulate food (leaf, litter, soils, wood etc.) and indirectly by affecting the structure and productivity of primary producers through shading and modifying the levels of organic carbon and nutrients (Behmer and Hawkins, 1986; Cummins et al., 1989; Bilby and Ward, 1991). The deforestation of riparian zones of streams removes shading and can result in a 2 to $5^{\circ} \mathrm{C}$ warming of small streams which has been found to greatly affect the life history characteristics of macroinvertebrates including their growth rate, survivorship, adult size and fecundity, and time of reproduction (Bilby and Ward, 1991). Therefore, species composition and abundance of Odonata in the forest could have been shaped by the presence and percentage of riparian vegetation of the water bodies. 
Findings from this study suggest that the survival of forest species of dragonflies and damselflies are being threatened as a result of rapid deforestation occasioned by rising human needs (e.g. deforestation and construction of buildings). Prevention of this anthropogenic activity is not feasible yet due to occupancy of plots of land by estate developers for residential purposes. Fragmented parts of the forest still have few forest species which can be protected. The larger part of the forest was dominated by ubiquitous species which are accustomed to human disturbance and are expected to still occupy the ecosystem as more residential buildings spring up as a result of urbanization.

In conclusion, this study has presented a checklist of odonate fauna in the degraded Iloyin Forest. The study could serve as a reference point for odonatologists who may want to carry out some studies on Odonata of the forest in particular and of Nigeria in general. This study has also established the interconnectivity of terrestrial and freshwater systems in the occurrence and distribution of Odonata. Finally, this study further underscores the significance of ecosystem conservation in a bid to conserve threatened species either locally or globally. The surest way to stem the current biodiversity loss of Odonata in the forest is to conserve the remaining forest which in turn would conserve all the microhabitats and their biota.

\section{Conservation Recommendation}

The odonate community structure in Iloyin forest will continue to depreciate since deforestation will continue in the area as an approved residential layout. Consequently, forest Odonata and the stenotopic ones may give way to the ubiquitous and eurytopic species. The water bodies seem healthy as revealed by the quality of odonate species sampled at the study sites. However when the layout becomes fully residential, most of the forest species sampled in this study will be missing. It is therefore recommended that the fragment of forest identified in this study be preserved and protected so as to serve as a reference point of what Iloyin forest was, before becoming a residential area. Finally, anthropogenic impacts on the forest streams should be checked and the streams' integrity preserved for the immature species of Odonata.

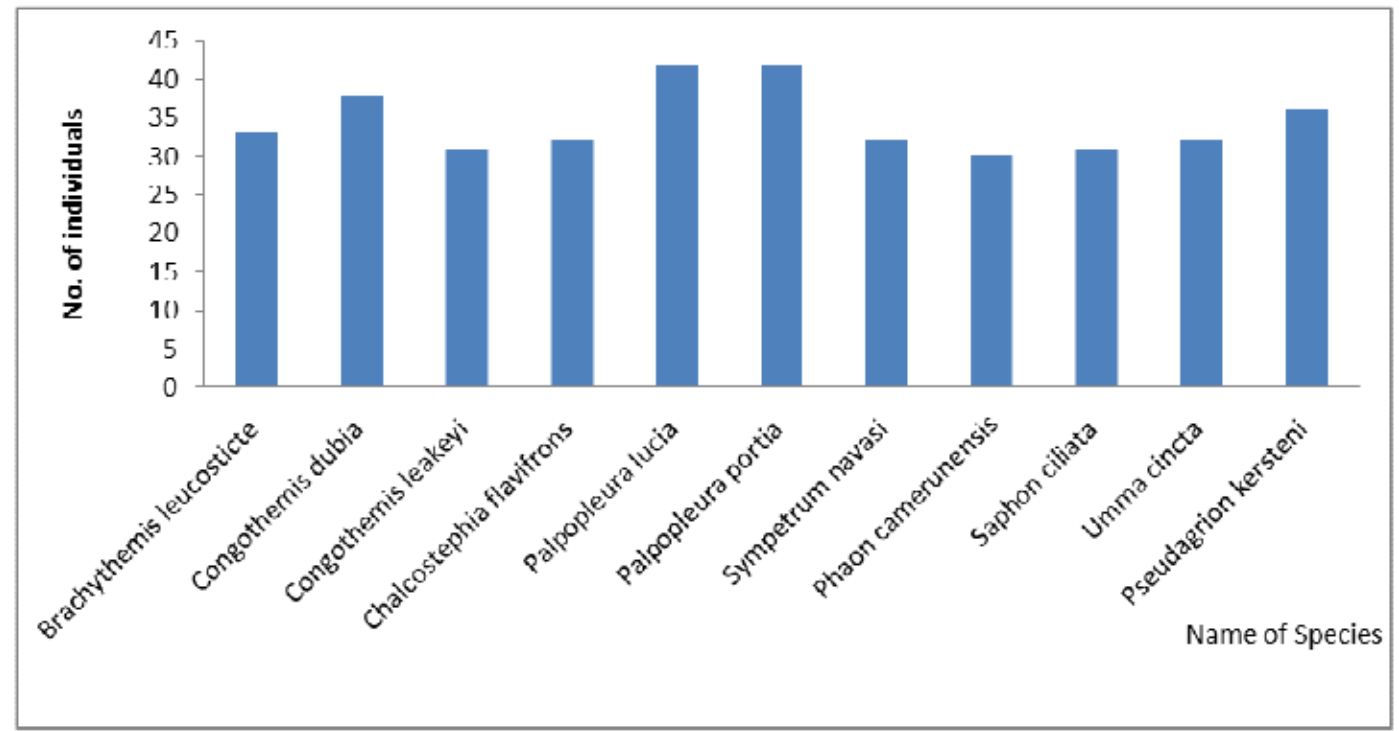

Figure 1: Dominant species of dragonflies and damselflies occurring in Iloyin Forest, Akure, Southwestern Nigeria (October-December, 2009) 


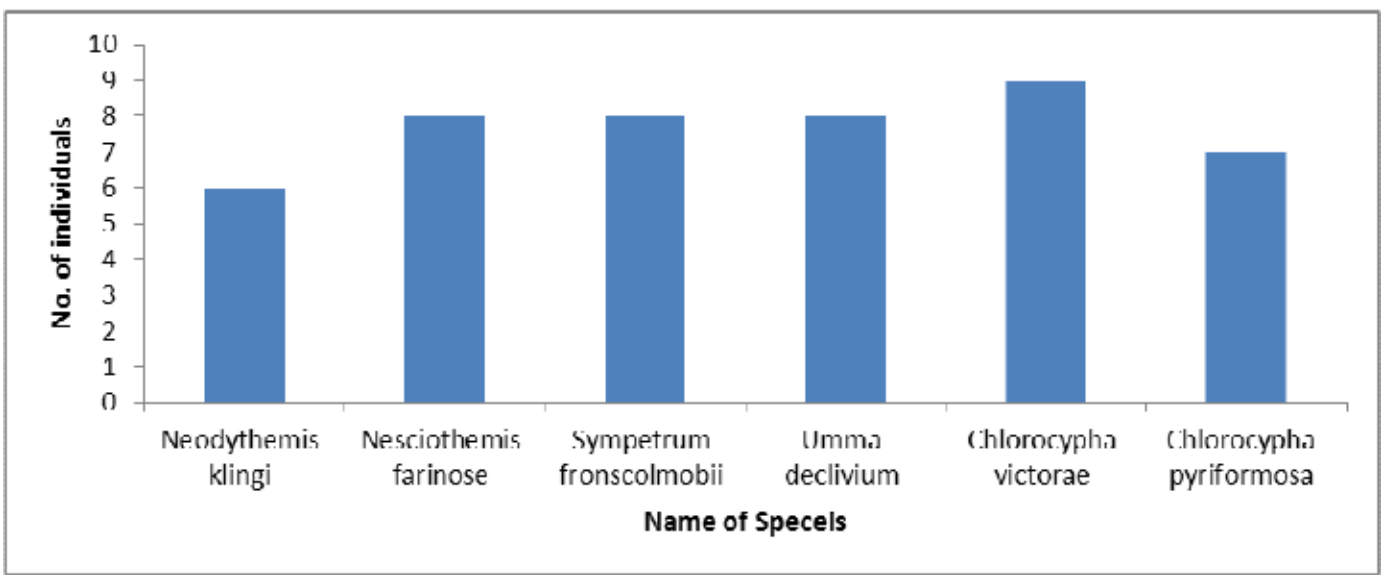

Figure 2: Rare species of dragonflies and damselflies in Iloyin Forest, Akure, Southwestern Nigeria (October-December, 2009)

Table 2: Ten most occurring species of Odonata collected in Iloyin Forest, Akure, Southwestern Nigeria (October-December, 2009)

\begin{tabular}{lll}
\hline Study site I & Study site II & Study site III \\
\hline Congothemis dubia & Congothemis dubia & Brachythemiis laustris \\
Pseudogrion kersteni & Palpoleura portia & Hadrothemis infesta \\
Chlorocypha curta & Palpopleura lucia & Umma cinta \\
Orthetrum Julia & Umma cinta & Congothemis erythraea \\
Pseudagrion risi & Sympetrum navasi & Congothemis sanguinonta \\
Elattoneura nigra & Platycypha eliseva & Sympetrum navasi \\
Phaon iridipennis & Pseudarion kersteni & Sapho ciliate \\
Chlorocypha consueta & Sapho ciliate & Umma mesostigma \\
Palpopleura portia & Platycypha auripe & Palpopleura portia \\
Palpopleura lucia & Ceriagrion glabrum & Palpopleura lucia \\
\hline
\end{tabular}

Table 3: Diversity and evenness of Dragonflies and Damselflies in the three Study sites of Iloyin Forest, Akure, Southwestern Nigeria (October - December 2009)

\begin{tabular}{lccc}
\hline Data & Study Site I & Study Site II & Study Site III \\
\hline $\begin{array}{l}\text { Number of } \\
\text { Individuals }\end{array}$ & 695 & 494 & 256 \\
$\begin{array}{l}\text { Number of } \\
\quad \text { Species }\end{array}$ & 69 & 49 & 51 \\
$\quad \begin{array}{l}\text { Number of } \\
\quad \text { Families }\end{array}$ & 8 & 7 & 7 \\
$\quad \begin{array}{l}\text { Shannon Wiener } \\
\text { index (H') }\end{array}$ & 4.19 & 3.83 & 3.80 \\
$\quad \begin{array}{l}\text { Simpson's Dominance } \\
\text { index (C) }\end{array}$ & 0.98 & 0.98 & 0.97 \\
Margalef index, $d$ & 10.39 & 7.74 & 9.02 \\
Evenness index (E) & 0.95 & 0.94 & 0.88 \\
\hline
\end{tabular}




\section{References}

Adetunji, J.F. and Parr, M.J. (1974). Colour change and maturation in Brachythemis leucosticte (Burmeister) (Anisoptera: Libellulidae). Odonatologica, 3(1): 13-20.

Adu, B.W. (2012). Biodiversity Assessment of Dragonflies and Damselflies (Odonata: Insecta) in Akure Forest Reserve, Ondo State Nigeria. PhD Thesis, Obafemi Awolowo University Ile-Ife.

Adu, B.W. and Ogbogu, S.S. (2011). Diversity of Dragonflies and Damselflies (Insecta:Odonata) in Obafemi Awolowo University, IleIfe, Southwestern Nigeria. Agrion 15 (1): 24- 31

Adu, B.W. and Ogbogu, S.S. (2013). The Diversity and Community Structure of Dragonflies and Damselflies (Insecta: Odonata) Aponmu Forest, Southwestern, Nigeria. International Journal of Agriculture and Forestry 3(6): $231-239$.

Adu, B.W. and Ogunjobi, A.A. (2014). Assessment of dragonflies and damselflies of Owena Forest, Southwestern Nigeria. International Journal of AgriScience Vol. 4(3): 153-159.

Ausden, M. (1996). Invertebrates In Sutherland, W. J. (Ed.), Ecological census techniques: a handbook. Cambridge University Press, UK, pp. 139-177

Barton, D.R. Taylor, W.D. and Biette, R.M. (1985). Dimensions of riparian buffer strips required to maintain trout habitat in Southern Ontario streams. N. Am. J. Fish. Manage. 5:364-378.

Behmer, D.J. and Hawkins, C.P. (1986). Effects of overhead canopy on macroinvertebrate production in a Utah stream. Freshwater Biol. 16: 287-300.

Bilby, R.E., and Ward, J.W. (1991). Characteristics and functions of large woody debris in streams draining old growth, clear cut and second-growth forests in Southwestern Washignton. Can. J. Fish. Aquat. Sci. 48: 24992508.

Bratton, J.H. (1991). British red data books 3. Invertebrates other than insects. Joint Nature Conservation Committee, Peterborough.

Che Salmah, M.R. (1996). Some aspects of biological and Ecology of Neurothemis tullia (Drury) (Odonata: Libellulidae) in laboratory and rain fed rice field in Peninsular Malasia. Ph.D Thesis, University Pertanian Malaysia, Serdand, Selangor, Malaysia.

Che Salmah, M.R. (2001). Studies of aquatic insects, with emphasis on dragonflies (Insecta: Odonata) as a tool in biomonitoring of freshwater ecosystem. BULLETIN, Vol.1, The School of Biological Sciences, University Sains Malaysia.

Che Salmah, M.R. and Wahizantul, A. Alfan. (2004). Distribution of Odonata (Insecta) in various ecosystems in northern Peninsular Malaysia. Wet Science 2: 184-191

Clausnitzer, V. (2003). Teinobasis alluaudi from mainland Africa: notes on ecology and biogeography (Zygoptera: Coenagrionidae). Odonatologica 32: 321-334.

Corbet, P.S. (1999). Dragonflies: behaviour and ecology of Odonata, Harley Books, Colchester. 
Cummins, K.W., Wilzbach, M.A., Gates, D.M., Perry, J.B. and Taliaferro, W.B. (1989). Shredders and riparian vegetation. Bioscience, 39: 24-30.

Dijkstra, K.D.B. (2006). Taxonomy and biogeography of Porpax and a dragonfly genus centre in the Congo Basin (Odonata, Libellulidae). Tijdschrift voor Entomologie 149: 7188.

Dijkstra, K. D. B. (2007). Demise and rise: the biogeography and taxonomy of the Odonata of tropical Africa. PhD Thesis, Leiden University.

Dijkstra, K.D.B., Clausnitzer, V., Boudot, J.-P., Kipping, J., Kisakye, J.J., Ogbogu, S.S., Samways, M.J., Samraoui, B., Schütte, K., Simaika, J.P., Suhling, F. and Tchibozo, S.L. (2011). Dragonflies and Damselflies of Africa (Odonata): history diversity, distribution, and conservation. In:
Darwall, W.R.T., Tweddle, D., Skelton, P., Smith, K. (Eds.), The status and distribution of freshwater biodiversity of Africa: underwater, under Threat. IUCN, Gland, Switzerland and Cambridge, UK, pp. 126-173.

Dijkstra, K.D.B., and J. Lempert. (2003). Odonate assemblages of running waters in the Upper Guinean forest. Archiv für Hydrobiologie 157: $397-$ 412.

Umar D. M, Milen G. M, Martin S, and Hazel, M.C. (2012). International Dragonfly Fund. Report 43: 1-53

Vick, G.S. (2003). Biodiversity Assessment of the Odonate Fauna of the Takamanda Forest Reserve, Cameroon. SI/MAB 8 (1): 73-82.

Wells, S.M., R.M. Pyle, and N.M. Collins. (1983). The IUCN invertebrate red data book. 